\title{
Utilising Action Research to Enhance Critical Social Work Practice: Ukraine's Experience of Introducing Community Paralegals
}

\author{
Kateryna Yeroshenko ${ }^{1}$ \\ ${ }^{1}$ Ukrainian Legal Aid Foundation \\ Rybalska Street, 2, Kyiv, 01011, Ukraine
}

DOI: $10.22178 /$ pos.51-3

LCC Subject Category: HV40-69

Received 11.10.2018

Accepted 29.10.2018

Published online 31.10.2019

Corresponding Author:

hilchevska@gmail.com

(C) 2019 The Author. This article is licensed under a Creative Commons Attribution 4.0 License @)

\begin{abstract}
The study was conducted to examine the course development process during which the perception of paralegal's role in local communities of Ukraine was shaped. Based on action research and critical social work paradigm the study demonstrates the role of training participants in constructing new knowledge, and how the understanding of paralegals concept in Ukraine had changed under their influence. The findings from a few cycles of action research reveal that there are fewer limitations to be a paralegal in Ukraine, as it was presupposed, paralegals role has shifted from only service brokerage and providing information, to conflict-solving, and providing new initiatives in local communities, moreover, the educational program for paralegals was changed in terms of their requests and according to their regional specifics.
\end{abstract}

Keywords: paralegal; Ukraine; action research; community advisers.

\section{INTRODUCTION}

The idea of paralegals is not new for a set of countries in different parts of the world: Philippines, Moldova, South Africa, China, the USA [1, 4, $9,10]$. But there wasn't any paralegals' experience in Ukraine till 2016 when the International Renaissance Foundation decided to implement paralegals work in local communities. In regional centers of Ukraine and large cities, the level of access to professional social workers or lawyers is quite high, educational institutions produce new specialists each year. But at the same time, plenty of communities do not have free access to such specialists, for example, in such communities as remote mountain villages, small towns, "dying out" rural areas, closed communities of indigenous, poor people, etc. Traditional legal aid providers do not always take into account the peculiarities of working with the poor, the vulnerable social groups, lawyers are looking for financial gain, complex legal cases. But the need of local communities is not in difficult cases but simple information and consultation. Moreover, people do not trust lawyers and think they are too expensive, so people either solve their problems in non-lawful ways or just don't solve problems. This attitude and resources distribution causes other ways to seek legal assistance and social support. Community paralegals are the answers to those problems. They are community volunteers who communicate in a clear language, have authority and trust in their communities, understand difficulties and problems, they are actively involved in community life [11].

The researcher was involved in the process of developing a community paralegals network from the very beginning within the advisory board, and decide to take the action research framework for constructing this process. Principles of action research arise from the idea of empowering people, and this is one of the main principles in social work practice. Action research in social work is based on recognizing strengths in all clients [2]. So when the researcher faced the need to develop a new construct of paralegals in Ukraine, which has to be explored and experimentally constructed, the answer to this need was action research as an intervention. The main idea was to bring people from various social and political contexts and backgrounds to identify, investigate who can be a paralegal in Ukraine, concerning the set of problems that faces local communities in Ukraine.

Action research was taken as a framework because all of the decision-making process -from 
the formation of research questions to the interpretation of the findings -everything was experimental and new to Ukrainian realities. Action research in this process was considered as a participatory process carried out by people affected by a problem or concern, concerned with developing practical knowing, it seeks to bring together action and reflection, often using a cyclical process to increase their understanding of the real problem before moving towards a solution shared new knowledge [8]. In this way, stakeholders became co-researchers: trainers, experts, the organization team, paralegals. As action research, the study was composed of cycles of reflection and action [7], and by these means, main initial ideas about who can be a paralegal, what their educational program should include, and their roles in the communities have been changed based on the participation of paralegals in the process. Their inclusion was based on the main principles of participation in action research to develop knowledge through empowering dialogue about modern views on critical social work paradigm $[3,6]$.

In the study researcher aimed to encourage participants to influent the process, so the closest understanding of the term "participation" in this survey is within the context of promoting development. Within the critical social work paradigm, effective participation recognizes not only the importance of involving all stakeholders in the development process [12], but also analyzing if doing so really increases the capacity of all to use the results of mutual decisions [5].

So the aim of this study is to review the creation of a new short-term training course and to analyze whether the less powerful group of the participants -paralegals (community advisers as they called under Ukrainian tradition) -are able to influence the study and to construct a new knowledge, and how the understanding of paralegals concept in Ukraine had changed under their influence.

There've been held 4 cycles of the research, there were a set of methods used within the research design in each cycle. Methods, cycles, groups of research participants, and the decisions which were made during each cycle are indicated in Table 1 . This paper focuses on community advisers (paralegals) perceptions and statements expressed during the different stages of the cycle.

Table - Research methods in accordance to the study cycles

\begin{tabular}{|c|c|c|c|c|}
\hline \multirow{2}{*}{ Cycle number } & \multirow{2}{*}{ Methods } & \multicolumn{3}{|c|}{ Research participants } \\
\hline & & Experts & Trainers & Community advisers \\
\hline \multirow{4}{*}{$\begin{array}{l}\text { Actions. } 1 \text { cycle: from the } \\
\text { initial expert meetings to } \\
\text { the end of the } 1 \text { training } \\
\text { module for community } \\
\text { advisers }\end{array}$} & $\begin{array}{l}\text { Desk-review } \\
\text { analysis }\end{array}$ & $\begin{array}{l}\text { Vision of the training } \\
\text { programme topics }\end{array}$ & & \\
\hline & $\begin{array}{l}\text { Training for } \\
\text { trainers }\end{array}$ & & $\begin{array}{l}\text { Training } \\
\text { methods } \\
\text { selected for } \\
\text { each topic }\end{array}$ & \\
\hline & Focus groups & \multicolumn{2}{|c|}{$\begin{array}{l}\text { Primary decisions of who can be a } \\
\text { paralegal }\end{array}$} & \\
\hline & $\begin{array}{l}\text { Educational } \\
\text { process }\end{array}$ & $\begin{array}{l}\text { Decisions of what was } \\
\text { useful within the } \\
\text { training course, } \\
\text { course redesign }\end{array}$ & & $\begin{array}{l}\text { Decision of who can be a } \\
\text { paralegal, Decisions of what } \\
\text { was useful within the } \\
\text { training course, request for } \\
\text { specific topics }\end{array}$ \\
\hline Reflections & $\begin{array}{l}\text { Feedback forms } \\
\text { on community } \\
\text { adviser activities }\end{array}$ & & & $\begin{array}{l}\text { Decision of what a paralegal } \\
\text { can do }\end{array}$ \\
\hline \multirow{2}{*}{$\begin{array}{l}\text { Actions. } 2 \text { Cycle: } 2 \\
\text { (Southern) set of } \\
\text { community advisers }\end{array}$} & Focus groups & $\begin{array}{l}\text { Vision of paralegals' } \\
\text { network development }\end{array}$ & & $\begin{array}{l}\text { Vision of the training } \\
\text { programme topics }\end{array}$ \\
\hline & $\begin{array}{l}\text { Educational } \\
\text { process }\end{array}$ & $\begin{array}{l}\text { Decisions of what was } \\
\text { useful within the } \\
\text { training course }\end{array}$ & & $\begin{array}{l}\text { Requests for additional } \\
\text { educational topics }\end{array}$ \\
\hline Reflections & $\begin{array}{l}\text { Feedback forms } \\
\text { on community } \\
\text { adviser }\end{array}$ & & & $\begin{array}{l}\text { Decision of what a paralegal } \\
\text { can do }\end{array}$ \\
\hline
\end{tabular}




\begin{tabular}{|l|l|l|l|l|}
\hline \multirow{2}{*}{ Cycle number } & \multicolumn{1}{|c|}{ Methods } & \multicolumn{1}{c|}{ Trainers } & \multicolumn{1}{c|}{ Community advisers } \\
\cline { 3 - 5 } & $\begin{array}{l}\text { Ections. } 3 \text { cycle: } 3 \\
\text { (Eastern) set of } \\
\text { community advisers, } \\
\text { additional; trainings for } \\
\text { the } 1 \text { set }\end{array}$ & $\begin{array}{l}\text { Educational } \\
\text { process }\end{array}$ & $\begin{array}{l}\text { Decisions of what was } \\
\text { useful within the } \\
\text { training course }\end{array}$ & $\begin{array}{l}\text { Requests for additional } \\
\text { educational topics }\end{array}$ \\
\cline { 2 - 5 } Reflections & Case study & $\begin{array}{l}\text { Feedback forms } \\
\text { on community } \\
\text { adviser activities }\end{array}$ & & Paralegals' success cases \\
\hline $\begin{array}{l}\text { Actions. } 4 \text { cycle: } \\
\text { community advisers } \\
\text { Forum }\end{array}$ & Focus groups & $\begin{array}{l}\text { Vision of paralegals' } \\
\text { network development }\end{array}$ & $\begin{array}{l}\text { Decision of what a paralegal } \\
\text { can do }\end{array}$ \\
\hline Reflections & $\begin{array}{l}\text { Researcher is still } \\
\text { in the process of } \\
\text { gathering } \\
\text { feedbacks }\end{array}$ & & & \\
\hline
\end{tabular}

\section{RESULTS AND DICUSSION}

The course development process. The process of this course development was designed in four steps.

The first step as international educational program analysis. Based on this analysis experts decided to make the course practical, designed as a set of training. All topics were united into three educational modules -"Human rights", "Community life", "System changes and cooperation", each of these modules lasts for three days, so the whole course lasts 9 days.

The second step was experts' meetings which were aimed to develop course content. According to experts' vision, the "human rights" module is dedicated to the understanding of the concept of "human rights" and introduction to basic human rights ideas. In particular, paralegals should achieve the idea of what human rights are, how to define situation of human rights violations, understanding the idea and the nature, and types of discrimination, understanding the characteristics of discrimination in different spheres of life, understanding of how to use this knowledge (consumer rights protection, labour rights, algorithm of what to do in those cases of violation, rules, and implications of contracting, including credit and online purchases. Also, the course participants should be familiarized with regional social services networks and free legal aid systems (governmental and non-governmental organizations) within this module. The second module "Community life" is focused on the understanding of community resources for problem-solving. Module "System Changes and Collaboration" provides an understanding of the process of ef- fective communication and integration of various services into the community. Also, this section covers the attraction of funds and the writing of project applications. Each section of the curriculum is composed of three components: theory, practical examples, visualization [11].

During the third step a pool of trainers was formed by the method of "snowball" - that is, each expert advised at least two trainers on the topic they were developing. Practitioners from regions were also selected on the criteria that they have training experience so they could conduct training for paralegals based on developed educational programs. Thus, a pool of 35 trainers was formed -12 in the first module, 12 in the second module, 11 in the third module. All trainers are practitioners in a human rights, service organization or legal aid organization.

The fourth step in the development of the educational program was training for trainers (TOT). A group of selected trainers presented the content of the program with the proposed teaching methods. The trainers were grouped in three by modules' topics, in those groups they worked in small teams on topics. After that, these teams presented their work (elements of their training sessions) for teams that represented other modules. Thus, at the end of the 3-day training, each trainer had feedback from colleagues on the relevance of the key issues, and on the training methods, they've chosen. In addition to all, TOT participants had the opportunity to discuss the content of the entire course together. All of them had an understanding of the whole course and the connections between different topics. Also as trainers were put in real situations, they could 
change the methods if some of them were ineffective. An important part of the TOT was a focus group discussion where trainers and experts brainstormed around paralegals and their functions in Ukraine, as well as the results of the discussions, was the initiated decision to call the Ukrainian paralegals "community advisers".

According to the discussion results community paralegals activities in Ukraine significantly differs from paralegals activities almost all around the world. In particular, their activities supposed to be less attached to legal advice, but more to social services, and services brokerage.

Experience of engaging and training community advisers. The first all-Ukrainian competition to take part in a community adviser's educational program took place in 2017. 30 participants were selected from 450 who applied. At the end of the third module, 23 participants passed the pilot training course and became the first set of community advisers. In 2018, the community continued to be recruited and expanded regional competitions and training of community advisers were held. Representatives from the southern regions of Odesa, Mykolayiv, Zaporizhzhia and Kherson regions studied in Odesa (Southern (2) set), and training for advisers from Kharkiv, Poltava, Donetsk and Luhansk regions were held in Kharkiv (Eastern (3) set).

The feedback from training participants allows determining changes in a vision on community advisers' decisions. In their feedback forms, community advisers left requests to the training program redesign. Such a redesign was made three times.

There were feedbacks from the first set of community advisers. They requested such changes: changes in the order of the educational modules 2 and 3, decrease attention to the decentralization process for community advisers told they are common with the topic, but increase attention to the budget processes at the local level. And also community advisers complain that the language is too difficult. The nationwide (first) set formed a request for leadership topic, but since it happened within the last module, a separate session on this topic was held for them in addition to the educational program.

After the first educational module of the second set, it appears that there were three topics of particular interest to community advisers in the region. They requested those topics to be included in the course: safety, public health, and education. Changes to the program were made in response to this request. As far as new health and education reforms in Ukraine are implemented, these topics were also included in the training program for the Eastern (third) set of community advisers.

After the third training module, community advisers of the Third (Eastern) set asked for more information about mediation, and other ways to resolve conflicts. Experts didn't take into account the regional specifics. In particular, there is an ongoing armed conflict with Russia in the Eastern part of Ukraine, and the region is divided into two parts - Ukrainian territories which are under Ukrainian rules, and Ukrainian territories that are occupied. There is only one person from occupied territory in the 3rd set, because it's difficult to go out and back to those territories, and there were more people who applied and were chosen, but they didn't come to the educational part. Still, the conflict-solving topic is of extreme interest for the whole 3rd set. They indicates many problems in their communities: destroyed buildings which are to rebuild, but the local governments have their view of what should be done in the community, they don't arrange consultations with the community members, there are also a lot of soldiers, and internally displaced people who moved from occupied territories to the closest communities. So there are many conflicts between these people who are new to the community, and usually, they have a proactive position, and the local government, who usually prefer to change nothing.

It is worth to note that community advisers influence the vision of what paralegal should do. For example, during the second cycle, it appears that community advisers do way more than was expected from them. One of the participants shares her experience of initiating a baby-club in the community.

"The idea of creating a Baby Club originated from the lessons of a community adviser with her little daughter. The community adviser decided to share her knowledge about babies' development. Since she works in the library, she decided to create a baby-club on the base of the library. For the organization of the club, the community adviser conducted a small survey among library users who have children from 2 to 5 years old and gathered a group of 5 children. So once a week community adviser or volunteers she in- 
volved work with kids to develop their speech, senses, motor skills".

Another community adviser opens the education allow club based on the library. She took informational leaflets from the government legal aid provision centre, and she made a stand in the library, where everybody can take leaflets. Also, she organized public disputes on problems in rights realization to reveal problems that are actual for the community. So community advisers started to organize their volunteer initiatives in their communities.

During the third cycle, community advisers show their creativeness in their initiatives. They began to unite in groups to solve typical problems in the region. They unite in several groups for now with different topics: "School mediation", "Youth leadership support", "Action against domestic violence", "Community safety", "Roma integration", "Instruments to influence local governments". Mostly those groups are regional, except for the group that works on youth leadership support.

Community advisers influence on the vision of who can be a paralegal. During the first cycle, experts decide upon a set of limitations about who can and who can't be a paralegal. But after the first set of community advisers' education, those limitations were changed.

First of all, the limitation for priests was canceled. There was a very active participant in the first set, he is a Roma activist, he usually took leadership. At the end of the course, it reveals that he is a priest in his community. If he wrote that in his motivation letter, he won't be chosen for the course, but in fact, it wasn't a problem, and he fits all of the other criteria in his community.

The same situation was with another community counselor, who was a representative of local government but didn't mention that in his application. He also fits the criteria: he has trust, authority, and respect in his community.

After these two cases, limitations for priests and government representatives were canceled.

So, the study proves the ideas of other researchers has been widely discussed in recent social work literature internationally $[2,3,6]$ that taking a participatory approach within the action research could be helpful in introducing new social work community practices and that modern educational formats must fashion itself to be 'fit for purpose of community development.
This study shows that not only community advisers have an influence on the research process of the action research, but also changes they've made were crucial to the understanding of who can be a community adviser in Ukraine, what they can do, and what they should learn.

\section{CONCLUSIONS}

In this study, the question was if community advisers (paralegals) could make changes in the decision-making process about their community. And they influenced the ideas of who can be a paralegal in Ukraine, what they can do, what they should learn. There are also some observations in the process which should be taken into account by anybody who wants to construct a new role in the society (or name an existing role that wasn't differentiated as a set of specific activities), teach a new complex constructs, and work with local activists, utilize the action research within the critical social work model . Here are those observations:

1. The experience of Ukrainian paralegals shows that experts should have taken into account the community contexts, but they couldn't because they are experts in certain topics on the national level, but not in regional communities tendencies. This can be seen in the example of the educational program design that was changed under the paralegal's influence and by the topics of community advisers initiatives, such as «mediation» and "community safety». It means that community advisers are experts in those community contexts. So this is a shift in the understanding of expertise in studies aimed to discover regional tendencies.

2. Understanding this point of expertise means that a researcher should think over the ways to involve people who usually are not considered as experts in the process of the research. In this study, it was done by the means of collecting feedbacks because those feedbacks are individual. Paralegals in a group tend to listen to leaders or «known-experts» and agree with them on public, but in their private feedbacks, they open their point of view which can be different. The idea here is to listen to everyone as everyone is an expert.

3. Such educational designs as in this study can be applied in teaching a group with a new role to society or a certain community, for new concepts usually need specifications and those changes are possible in such a model. 


\section{REFERENCES}

1. Berenschot, W. \& Rinaldi, T. (2011). Paralegalism and Legal Aid in Indonesia: Enlarging the Shadow of the Law. Retrieved from https://namati.org/resources/paralegalism-and-legal-aid-in-indonesia2011/

2. Branom, C. (2012). Community-Based Participatory Research as a Social Work Research and Intervention Approach. Journal of Community Practice, 20(3), 260-273. doi: 10.1080/10705422.2012.699871

3. Fenton, J. (2014). Can social work education meet the neoliberal challenge head on? Critical and Radical Social Work, 2(3), 321-335. doi: 10.1332/204986014×14074186108718

4. Franco, J., Soliman, H., \& Cisnero, M. R. (2018). Community-Based Paralegalism in the Philippines. Community Paralegals and the Pursuit of Justice, 96-138. doi: 10.1017/9781316671801.003

5. Hansson, J., Höög, E., \& Nyström, M. (2016). Action research for multi-level facilitation of improvement in health and social care: Development of a change facilitation approach for a local R\&D unit. Action Research, 15(4), 339-356. doi: 10.1177/1476750316650928

6. Hatton, K, (2015). New Directions in Social Work Practice (2nd ed.). London: Learning Matters.

7. Heron, J., \& Reason, P. (2001). The Practice of Co-Operative Inquiry: Research with Rather than on People. In P. Reason, H. Bradbury (Eds.), Handbook of Action Research: Participatory Inquiry and Practice (pp. 179-188). London: Sage.

8. Stringer, E. T. (2007). Action Research (3d ed.). London: Sage Publications.

9. Warner, R., Elias-Jermany, C. \& Elias, S. (2004). Independent Paralegal's Handbook. How to Provide Legal Services without Becoming a Lawyer (6th ed.). Berkley: NOLO.

10. Xing, Y. (2014). Dissemination of Law and Access to Justice at the Village Level: A Case Study of Barefoot Lawyers in the Villages of China. Positions: Asia Critique, 22(3), 603-633. doi: $10.1215 / 10679847-2685395$

11. Yeroshenko, K., \& Semigina, T. (2017). Creating a training programme for community-based paralegals: action research. Social Work and Education, 4(2), 33-45.

12. Zornes, D., Ferkins, L., \& Piggot-Irvine, E. (2015). Action research networks: role and purpose in the evaluation of research outcomes and impacts. Educational Action Research, 24(1), 97-114. doi: $10.1080 / 09650792.2015 .1045538$ 